\title{
Racialization of Knowledge: How the Marginalization of Black History and Knowledges Fosters a Lack of Racial Literacy among Teacher Candidates
}

\author{
Patrick Radebe \\ Lakehead University, patrick_radebe@hotmail.com \\ Bathseba Opini \\ University of British Columbia, bathseba.opini@ubc.ca
}

Follow this and additional works at: https://pdxscholar.library.pdx.edu/nwjte Let us know how access to this document benefits you.

\footnotetext{
Recommended Citation

Radebe, Patrick and Opini, Bathseba (2021) "Racialization of Knowledge: How the Marginalization of Black History and Knowledges Fosters a Lack of Racial Literacy among Teacher Candidates," Northwest Journal of Teacher Education: Vol. 16 : Iss. 2 , Article 8.

DOI: https://doi.org/10.15760/nwjte.2021.16.2.8
}

This open access Article is distributed under the terms of the Creative Commons Attribution-NonCommercialShareAlike 4.0 International License (CC BY-NC-SA 4.0). All documents in PDXScholar should meet accessibility standards. If we can make this document more accessible to you, contact our team. 


\title{
Racialization of Knowledge: How the Marginalization of Black History and Knowledges Fosters a Lack of Racial Literacy among Teacher Candidates
}

\begin{abstract}
This paper examines the practice within universities of restricting the number of courses focussing on Black/African-Canadian history and 'Blackness', in the context of teacher education programs, and the implications for the unawareness of racial literacy among teacher candidates. The lack of such courses at select universities in Western Canada is discussed, as are the consequences for teacher candidates. Teacher education programs can address the systemic gaps in Black history courses and Black knowledge systems and better serve the interests of students by, offering courses that centers Black worldviews and hire Black scholars to foster a more equitable learning environment.
\end{abstract}

\section{Keywords}

Anti-racism, Teacher candidates, racial literacy, Black history, universities, Blackness, racism.

\section{Creative Commons License}

cc) (i) (2)

This work is licensed under a Creative Commons Attribution-NonCommercial-Share Alike 4.0 International License.

\section{Cover Page Footnote}

The authors would like to thank the anonymous reviewers of the article for their feedback which helped strengthen the manuscript. 


\section{Introduction}

The bulk of the curricula offered at Canadian universities speaks to the racialization of knowledge, a process that both reflects and reinforces Eurocentric cultural and racial hegemony. This is evident in the context of teacher education programs where curricula are lacking in diversity, and Black history is ignored, a practice that fails to foster racial literacy among teacher candidates. Aware of the implications of what is apparently an intractable challenge, Black Canadian educational scholars (Dei, 1996; 2008; 2013; Henry, 1993; James, 1995) have called for systemic changes to $\mathrm{K}$ to 12 and university curricula to reflect the racial and cultural diversity of Canada.

The response to this problem on the part of government remains inadequate when it comes to addressing calls to reform educational curricula. For example, in February 2021, Global News journalist Sean Boynton (2021) reported that the British Columbia (B.C.) Minister for Education indicated support for teaching Black history at all levels of the $\mathrm{K}$ to 12 education system in British Columbia. Similarly, the Premier called on all British Columbians to "take time to learn about Black history and the ways in which Black Canadians have shaped our communities and our province" (Boyton, 2021, para. 20). While well intentioned, such pledges are empty of any real commitment to follow through with action. How can British Columbians learn about Black people if the requisite knowledge is nowhere to be found in the education curricula?

This paper uses examples from two universities in British Columbia to show how teacher-training programs erase Black people's knowledges, thus reinforcing anti-Blackness and thwarting the educational ambitions of Black students. As Black academics, we routinely receive complaints from Black students regarding the lack of courses on Black history and Black representations within teacher education. We write this paper, drawing on our teaching experiences, and with three goals in mind: First, we wish to affirm what other Black scholars have written on the scarcity of courses on Black history within the Canadian education system (Codjoe, 2006; Dei, 1996; Henry, 1993). Second, we wish to show that in teacher education programs, the lack of Black-centered courses and the practice of conducting ad hoc workshops on race, often complemented by Black History Month (BHM), work to perpetuate a lack of racial literacy among teacher candidates. Lastly, we wish to impress upon universities, and especially Faculties of Education, the need to include in their curricula, courses on Black history and knowledge systems. We argue that not having Black history courses works to erase Blackness. The lack of Black epistemologies and worldviews in teacher education works to deny Black teacher candidates, and all of their non-Black peers, the opportunity to develop an 
understanding of anti-Blackness, anti-Black racism and their implications. We hope that this paper will spark a dialogue aimed at addressing this systemic challenge.

In this paper we use the terms 'Black African', 'Black African-Canadian', and 'Black' interchangeably to refer to persons who Africa is the locus of their ancestry. The phrase 'lack of racial literacy' is used to signify a lack of understanding on the part of non-Black teacher candidates, of Black history/knowledges and the struggles of Black peoples against racism that is normalized and naturalized while at the same time denied. We also reference other racialized groups to emphasize that not only white people propagate antiBlackness and anti-Black racism; but both are very much alive within other racialized communities, perpetuated by the universalization of false racial hierarchies (Morikawa, 2001).

We use the term 'Blackness' to denote the state or condition of being Black, that is, of identifying with and valuing one's Black African heritage and the life experiences contingent upon it. Blackness involves celebrating one's Black identity and using it to oppose efforts to marginalize and subordinate Black people. Anti-Black racism is used to imply racism directed at Black people and their resistance to such oppressions (Benjamin, 2011). The continued erasure of Black history and knowledges in contemporary contexts is a serious global phenomenon that leaves non-Black people with limited understanding and recognition of anti-Black racism as a scourge that must be contested and dismantled in all its disparate forms.

\section{Theoretical Framework}

The theoretical framework of Afrocentricity informs this work. Molefi Asante (2003a) defines Afrocentricity as a mode of thought and action predicated upon African interests, values, perspectives and collective historical experiences. Midas Chawane (2016) posits that Afrocentricity opposes "the intellectual colonialism that undergirds and serves to validate political and economic colonialism" (p. 80) of Black people. Afrocentricity rejects colonial narratives and representations and focuses instead on making African peoples active agents, of their own history, rather than objects of study (Asante, 2003a). An Afrocentric approach empowers Black people to value their culture and assert themselves in the world (Asante, 2003a). Afrocentricity highlights Black contributions to humanity. It offers alternative worldviews that challenge entrenched Eurocentric knowledge and beliefs that work to normalize whiteness and privilege white people while denigrating Blackness and signifying Black people as lazy and irresponsible freeloaders that view Canada as a welfare haven. An Afrocentric perspective problematizes these stereotypes, which often translate into differential treatment 
of Black students in the education system (Dei, 1996). Afrocentricity allows other cultures to view history from their own perspective" (Chawane 2016, p. 85). It troubles the intellectual project of neo-colonialism and its practice of privileging European knowledges and experiences over that of other peoples (Chawane, 2016).

According to Asante (2007), Afrocentricity affirms and validates Black experiences, histories, cultures, and knowledges as rich and valuable resources that can inform the teaching and learning process. For example, one of us once introduced a class consisting of teacher candidates to an important occurrence in the history of Black Africans in Canada. The students learned about the Oro African Methodist Episcopal Church, one of the last remnants of a community of Black Canadians. The church serves as a reminder of the crucial role Black people played in defending Upper Canada in the War of 1812 (Canada's Historic Places, n.d.). Very few teacher candidates are aware of this history. As Asante (2007) remarked, "the most productive method of teaching a student is to place that student within the context of knowledge" (p. 79). For Black teacher candidates, this is key to understanding who they are as Black people and to learning their history, which has been distorted or concealed for centuries. Employing an Afrocentric framework in teacher education works to dispel knowledge falsehoods about Black people. It addresses the practice, within the education system, of erasing Black history and marginalizing Black students. Afrocentricity could be used to advocate for culturally responsive educational programs designed to address the oppression and alienation of Black students' educational experiences (Asante, 2003a; Lateef, 2015).

As educators, we are committed to problematizing Eurocentric narratives by embedding, in our course syllabi and in our teaching, anticolonial and antiracist works by leading scholars in the field. We also strive to provide a safe and respectful learning environment, one that allows students to nurture their ideas through an Afrocentric prism. For example, with a view to interrogating Eurocentric narratives in a Bachelor of Education class, one of us referenced the role played by Black women in building $19^{\text {th }}$ century Canada. The women included Maria Gibbs, reputed to be the most educated woman in colonial Canada; Clarissa Richard, one of the foremost advocates of female suffrage; and Annie Norton an opponent of racism and patriarchy (Kilian, 2008). The achievements of these women, which are often untold, provided female teacher candidates, especially Black students, with a sense of pride in the contributions of Black female pioneers to pre-confederation Canada. The stories of these women continue to inspire contemporary Black women to resist racism, colonialism and patriarchy. These examples, and that of other Black women in Canada and globally, as revealed through the lens of an Afrocentric education, serve to bolster confidence in Black teacher candidates' ability to interrogate Eurocentric 
knowledges, often passed down through generations and privileged as legitimate, natural and universal.

Nonetheless, the theory of Afrocentricity has been criticized for failing to take up discourses of other racial groups (Wright, 2000). Scholars, including Crouch (1995) and Lefkowitz (1996) argue that Afrocentricity lacks serious historical investigations. In response to these criticisms, Asante (2003b) explains that Afrocentricity is "against all forms of oppression, including racism, classism, homophobia, patriarchy, child abuse, pedophilia and white racial domination" (p. 2). That said, Afrocentricity's principal focus lies in promoting Black consciousness by, among other things, foregrounding the challenges confronting all Black people and their communities.

In spite of the criticisms, Afrocentricity has a key part to play in understanding how the absence of Black history courses and knowledges within the context of teacher education programs can negatively impact Black students at every level. In the case of Black teacher candidates, it enables them to see themselves reflected in the curriculum, learn of the achievements of Black people and their communities, and use the knowledge they acquire to challenge antiBlack racism (Morikawa, 2001). An Afrocentric framework offers a useful perspective for subverting normalized colonial modes of thought, replete with racist typecasts of people of African descent (Asante, 2003b).

\section{The Erasure of Black History and Knowledge Courses in Teacher Education Programs}

In this section, we focus on examples of curricula at two teacher education programs in British Columbia: Simon Fraser University (SFU) and the University of British Columbia (UBC). SFU offers a Bachelor of Education degree through both its Professional Development Program (PDP) and Professional Linking Program (PLP). The PDP is a 16-month-long full-time, post-degree program. The PLP, allows teacher candidates to pursue certification while continuing to work in education or child or youth-related positions, such as student support workers, education assistants, child and youth care workers, counsellors, settlement workers and independent school educators (SFU, 2020). The UBC offers both a consecutive 11-month teacher education program and a dual degree teacher education program in collaboration with five other departments and/or faculties. The focus here is on the Simon Fraser University's PDP and the University of British Columbia's 11-month program.

To qualify for B.C. teacher certification, teacher candidates enrolled in Simon Fraser University's PDP program must complete 18 mandatory courses and a practicum. Elementary, middle school and secondary teacher candidates enrolled in the UBC's 11-month program must also complete 18 mandatory 
courses, in addition to two practicums. None of these mandatory courses relates directly to Black knowledge systems, notwithstanding the commitment on the part of both education departments, to "social justice, equity, sustainability and social action" (UBC, 2020) and to "ethical practice, equity, social justice and diversity" (SFU, 2020). At UBC, for example, while mandatory teacher education courses such as Education, School and Social Institutions and Development, Learning and Culture in the Classroom provide instructors a degree of latitude so far as investigating Black history and knowledges is concerned, few are so inclined. The three-week Community Field Experience program for UBC teacher candidates offers another opportunity to learn something of Black history. While some avail themselves of the opportunity by opting to do this learning in African countries, including Kenya, Uganda and Tanzania, where mostly non-profit organizations have partnered with the Faculty of Education's Teacher Education Office, which oversees the teacher education program; these one-off experiences are insufficient to dispel long-held racist and stereotypical perceptions of Black people and Africa.

Exposing white teacher candidates to African history and knowledges often times helps them achieve their occupational goals, including securing employment. This approach is, however, problematic in that it allows Eurocentric universities to continue the practice of tokenizing African history with a view to advancing a neocolonial agenda, the purpose of which lies in maintaining whiteness as a dominant system. From an Afrocentric perspective, while whitedominated universities offer a limited number of Black courses, they do so not to undermine white exceptionalism but, rather, to mollify galvanized Black communities. The benefits accruing to white teacher candidates lie in improving their employment prospects by flaunting their knowledge of Black history as well as their commitment to equity and social justice within the public education system (Boykin, 1994; Murrell, 1993; Woodson, 1993) without dismantling antiBlack racism.

For the past seven years, we have both taught courses for teacher candidates that focus on decolonization, equity, race, antiracism, and social justice. Thus, we have significant experience working with students within the context of teacher education programs offered at our respective universities. At present, these programs include not even one course on Blackness or on the history and knowledges of Black people. On numerous occasions during class discussions, we have observed how Black teacher candidates often remain silent, ostensibly because they feel alienated by the readings they are assigned. During a class focusing on equity, a Black teacher candidate spoke of how multicultural narratives pay lip service to promoting "Othered" histories and knowledges. White teacher candidates were appalled because they took it for granted that multicultural education places Black history on a par with all other histories so, 
why the complaints? It would appear that the act of articulating Black experiences was for them the cause of much discomfort.

Our experience working with teacher candidates reveals that this systemic gap in Black history courses, literature, and knowledges, leads to the discounting or dismissing of Black peers and instructors. It is often the case that any challenge to normalized Eurocentric views is met with discomfort, hostility and denial. Some argue overtly that Black students and professors exploit every opportunity to advance a race-based agenda that vilifies Euro-American narratives and the knowledges that inform them. Even some non-white teacher candidates echo these sentiments. For example, during a class discussion, a student of Mexican heritage who was born and raised in Canada claimed that Afrocentric theory and education constituted an ideological project. The student added that class discussions on race were invariably pro-Black and that Black people should get over the past. The student's views reveal, in our opinion, the pervasiveness of anti-Black racism. They also remind us that some racialized people too harbor anti-Black bias and view Black people unfavourably. The loathing of Black experiences and counter narratives on the part of non-Black teacher candidates, silences Black students and denies white and other racialized teacher candidates the opportunity to learn about Black history.

According to Dlamini (2002), “...most [white teacher candidates] subscribe to the myth that Canada is a "non-racial', functionally multicultural country, where people of different ethnic backgrounds enjoy the same privileges" (p. 59). "Students who subscribe to this myth dismiss the notion that mainstream universities with their "open enrolment policies" deliberately marginalize Black history and knowledges. When interrogated on this matter, white teacher candidates "respond with anger because they feel challenged." Dlamini (2002) further argues that white loyalty to a European heritage and disdain for Black African history, especially in the context of higher education, "is the result of [racial] identification" (p. 60). For white teacher candidates, Black history provides a narrative cataloguing, among other things, white atrocities and oppression. It signifies Black people as an oppressed group entitled to compensation in the form of an admission of white guilt. What white and other racialized teacher candidates ought to understand is that learning Black history written from a Black perspective is crucial to their self and professional improvement. Afrocentricity provides teacher candidates with the requisite tools to interrogate the deep-seated paradoxes inherent in a neo-colonial model of thought (Asante, 1993). It exposes teacher candidates to alternative knowledge systems that enable them to challenge Eurocentric models of thought that are often masked as multicultural education, an operation that inhibits their appreciating Black history and challenging Eurocentric curricula and pedagogies. 
Daniel (2019) and Henry (2015) also show that racist attitudes towards Black academics have not changed within Canadian institutions of higher learning. In white-dominated universities, Black professors' authority and qualifications are often questioned. And while they are afforded a space to "speak [about] any [subject], [they] are not afforded the dispensation to name . . . raceand specially anything related to Blackness" (Daniel, 2019, p. 22; Henry, 2015). Black professors who defy this injunction are "framed as biased, 'racist' and hating white people" (Daniel, 2019, p. 23). Those disliked by students and/or whose courses are viewed as controversial receive unfavourable evaluations, along with comments recommending they be fired (Henry, 2015). Many Black professors soon discover they have been abandoned by their white peers as well as university administrators and that "their investment in social justice is regarded as a personal rather than an academic and intellectual pursuit" (Daniel, 2019, p. 25; see also Mohamed \& Beagan, 2019).

\section{A Lack of Black History Courses is Short-Changing Students}

Both UBC and SFU tend to remember February as Black History Month. However, while highlighting Black marginalization and oppression, these institutions largely ignore the achievements of Black people. Although Black oppression is very real, it does not represent the sum of Black people and their experiences. Nonetheless, come every February, Education Department websites are filled with announcements inviting faculty to participate in workshops, seminars, speaker panels, history classes and social activities pertaining to the Black experience and to provide a list of learning resources, i.e., African artefacts and posters and short videos featuring Black heroes. This tokenistic approach is antithetical to promoting inclusive teaching and learning; it also limits the possibilities for in-depth engagement with "Othered" knowledges. Such piecemeal approaches to Black history and 'Blackness' nurture, among teacher candidates, a lack of awareness regarding what might constitute a racially and culturally responsive, antiracist and decolonizing pedagogy (Flynn et al., 2018; Henry, 1993).

On other occasions, Black teacher candidates have recounted the experiences of instructors who have attempted, albeit in vain, to discuss Black history beginning with the trans-Atlantic slave trade and the underground railroad. Yet, what is seldom examined is the real history of Black people, a history that goes back thousands of years and that captures the great civilizations of the African continent. The white rendition of Black history is a watered-down version of Black contributions, experiences and models of thought. Moreover, Eurocentric versions of Black achievements are often limited to the fields of sports and entertainment. And those Black heroes referenced occasionally in Black history 
courses of whom Martin Luther King Jr. is an example, are invariably those whose views are moderate, and thus qualify for inclusion in school curricula. Martin Luther King Jr.'s views on race relations were accepted by most white people as opposed to those of Malcolm X, a Black revolutionary leader who gained fame among trans-Atlantic Black Africans during the Civil Rights era but was branded a terrorist by white people, particularly in America. In a headlong rush to graduate teacher candidates so that class space might be created for a new cohort of students, education faculties deny white teacher candidates the requisite knowledges and skills to interrogate Eurocentric epistemes and curricula that frame Black history as inconsequential to the academic, social and professional life of white students and the education system as a whole.

Normalizing the absence of Black history allows non-Black teacher candidates to assume that Black African history courses are not relevant to their intellectual and pedagogical development (Flynn, et al., 2018). As a result, on those rare occasions when confronted with the reality of white oppression, many teacher candidates limit themselves to expressing "feelings of guilt or paralysis" (Flynn, et al., 2018, p. 242). Rare and brief encounters with Black knowledges and experiences cannot dispel inaccurate and racist representations of Black heritage that are commonplace in the curriculum and have dire implications for the acquisition and application of knowledge. For equitable teacher education programs to function, the teaching process must extend beyond the curriculum; and it must be inclusive, which means courses on Black history and culture must be offered. It also means that teacher candidates must be presented with knowledge systems that foreground Black history and culture-knowledges often left untold, distorted or dismissed.

\section{Eurocentric Universities and the Erasure of Black History}

There is a common belief that Canadian universities constitute neutral spaces where knowledge is created and disseminated, yet the reality is very different. European knowledge systems are used as benchmarks against which all other knowledges are ranked. Black knowledges and histories are seen as mere curiosities or classified as esoteric. Whiteness as a system continues to be operationalized through curricular design that works to stimulate the intellectual curiosity of white students while, knowingly or unknowingly, promoting racism and silencing Black students.

In their study with racialized faculty members, Henry and Tator (2012) found that Canadian universities perpetuate racial disparities by weighting budgets in favour of Eurocentric curricula. At the same time, senior faculty and administration determine which courses and programs qualify as valid conduits of knowledge and which do not. Often, the choices made reproduce, within 
academe, white hegemony regardless of the implications for racialized students. As Henry and Tator (2012) note:

[The] curricula communicate the message that only particular kinds of knowledge are validated and valued. Eurocentric frameworks and content are often given more resources and curriculum spaces, but also more dominance and status . . . Many racialized and Indigenous faculty have suggested that only specific types of knowledge continue to be recognized as legitimate, thereby excluding other forms that diverge from the Eurocentric norm. (p. 81 - 82)

Universities, and in this context teacher education programs, continue to promote Eurocentric knowledges and domination. It is highly unusual for any Canadian university to include courses on Black history, i.e., pre-colonial and colonial African history, contemporary Africa and African diaspora, the slave trade, African American slaves on Virginia cotton plantation, Black innovations etc., and knowledges, and certainly not those accredited for teacher certification, as part of its teacher education curriculum. Curriculum gatekeepers work to ensure that certain courses, especially those informed by Black perspectives, are excluded on the grounds that they embody a confrontational, indeed revolutionary, approach to knowledge acquisition - one that challenges the position of white people as sole arbiters of knowledge. To absolve themselves of blame, universities hire a token number of Black professors, often as contract faculty, and offer a token number of courses focusing on racial equity and social justice, but not Black history per se. As Henry and Tator (2012) note, "hiring drives curriculum, the curriculum drives hiring" (p. 82) as part of an unspoken 'policy' to reproduce white hegemony within academe.

According to Levine-Rasky (2014), reluctance on the part of Eurocentric educational institutions to teach knowledges of Black people stems from a white people's fear of Black consciousness and a determination on the part of Black communities to resist white domination. By marginalizing Black history courses and knowledges, mainstream universities can deny Black students knowledge that might promote their emancipation and self-determination. Argues Levine-Rasky (2014):

[Universities] fear the possible outcome of an education sufficiently radical to produce a self-determining, Afrocentric subjectivity. [This] fear is immanent in the knowledge that who one is and what one has are not the results of [one's just] deserts or natural merit. (p. 214) 
The stark reality illuminated by Levine-Rasky (2014) is not unique to Faculties of Education. Moreover, the precarious financial health of some universities mean that Black history courses are the first victims of retrenchment when budgets are cut.

\section{Black People and Black History as viewed through a Neocolonial Prism}

Along with the absence within teacher education programs of courses on Black history and knowledges, there lies the additional challenge of how the elective and required readings signify Black people and culture. Giroux and McLaren (1989) argue that textbooks are foundational to shaping students' understanding of a people and their history. Most texts focusing on Black people and Africa propagate stereotypical representations of Blackness while positioning white people as the progenitors of civilization. In the case of Black teacher candidates, success is measured not in terms of their creativity, or proficiency in Indigenous Black African languages or ability to hold forth on some aspect or other of Black African culture. Rather, the only metrics that count are fluency in a colonial language, proficiency in making sense of the Black experience from a colonial or neocolonial perspective, and knowledge of Eurocentric teaching methodologies, however disconnected from the lived experience of Black and other racialized students.

It is also the case that many texts within university curricula present Black African countries as a locus of hunger, misery, chaos and death (James \& Brathwaite, 1996). It is by no accident that the highly sophisticated pre-colonial cultures of sub-Saharan Africa are ignored or glossed over. Black African history, it is assumed, begins with the European discovery of a 'dark continent', frozen in time, and awaiting rescue by Western civilization (Dei, 2010). For its part, contemporary Africa is signified as a homogenous space, plagued by disease, war and eternally corrupt, incompetent, authoritarian leaders (Manzo, 2006). Such Eurocentric representations, to which teacher candidates are exposed, are part of the neocolonial project to exalt whiteness at the expense of Blackness. They are an extension of a missionary enterprise to promote white paternalism while infantilizing Black Africans (Wright, 2012). At mainstream universities, what passes for knowledge of Black Africans is culled from the playbook of the $19^{\text {th }}$ century colonial narratives that portray Africa as inhabited by savages (Wright, 2012).

We cannot overstate the impact of colonial/racist narratives and representations on teacher candidates and hence their future students. This point requires illustration. A few years ago, one of us was invited to present to a group of teacher candidates, enrolled in one of the teacher education programs cited here, on the topic of social justice in education. The teacher candidates, who were 
predominantly white, were asked to record on paper what they thought of Africa and Africans. What follows is a representative sample of the descriptors used.

- $\quad$ Continent, poverty, safari

- $\quad$ Black, desert, dependent on Christian help

- $\quad$ Safaris, huge continent, extreme poverty in some areas, lots of people

- $\quad$ Animals, poverty, hunger, heat, AIDS

- $\quad$ Small, uneducated population, comprised mainly of Black people

- Underdeveloped part of the world with great poverty; diversity, different cultural traditions, marginalized, sometimes discriminated against or treated differently, not a lot known because not taught.

Consistent with existing colonial and racist stereotypes and imagery, the language used here portrays Africa as a 'dark continent' (Macheso, 2017), devoid of 'civilization', and its people devoid of agency. Consistent with mainstream myths, Africans are represented as uneducated, poverty-stricken and disease-ridden, antipathetic to modernity and dependent upon "Christian help", presumably in the form of foreign aid from the West. These depictions reinforce white exceptionality, a bedrock principle underlying colonialism. When teacher education programs eschew holistic representations of Africa, they foster a culture of ignorance about Africa and Africans that goes unchallenged. This undercuts efforts to restructure the curriculum while at the same time denying students the opportunity to learn how to interrogate racist texts, a first step to becoming critical consumers of knowledge.

This way, teacher education programs continue to promote knowledge systems that are not only racist in orientation but also aim to reproduce European hegemony (Pinar, 1993). As agents of white supremacy, universities are complicit in rendering Black history and knowledges inconsequential, hence Pinar's (1993) observation that:

... The Eurocentric character of [teacher education programs and the] curriculum [in general, as evinced in the paucity of courses focusing on Blackness] functions not only to deny [Black students] role models, but to deny [white teacher candidates] self-understanding as well. (p. 61-62)

King and Simmons (2018) concur with Pinar's (1993) view that universities enforce white domination by, among other things, failing to prepare teacher candidates to teach Black history: 
Much of the literature ... indicate[s] that teachers' Black history instruction is poorly constructed. With a heavy reliance on textbooks, teachers may miss the nuance of topics salient to Black historical experiences such as race, racism, white supremacy, and the diversity of Black culture. (King \& Brown, 2014 as cited in King \& Simmons, 2018, p. 97)

By erasing or ignoring Black history, universities perpetuate white-centric knowledge hierarchies that reinforce whiteness. Almost inevitably, teacher candidates, come to assume, if they haven't previously, that European history, knowledges and literature are incomparably superior to all alternatives and for this reason ought to, indeed must, be taught in schools. They fail to perceive, let alone question, the racially informed power differentials that historically have shaped knowledge production and dissemination and continue to do so.

\section{The Consequences for $\mathrm{K}$ to 12 Students}

We use Allen's (1996) experience with elementary school students to show how a lack of racial literacy among teachers can contribute to fostering low self-esteem, even self-loathing, among Black and other racialized students. Students' responses to illustrations of Black characters in children's picture books," Allen (1996) examines the impact on Black students of negative representations of Blackness. He describes how some of his grade 2 students became upset when confronted with both the "angry, sad or pensive" (pp. 157) characters depicted in The Orphan Boy, "a Maasai folktale[,] and ... [the] illustrations that portray[ed] the characters in a harsh, dry, primitive environment" (Allen, 1996, p. 157). When asked what they found so objectionable about the characters, the students responded, variously:
Leo: "My head (face) is not like that. I don't have anything Black here."
Ralph: "That looks like a moustache .... No, that doesn't look like me, I am brown Black, he's light Black and [the other character is] dark Black."
Mike: "Because I don't like his face. It is his head; it is covering here... on his moustache."
Theodore: "The face does not [look] good."
Maggie: "I can't see the eyes." (p. 158)

The responses on the part of these students reveal how racism and racist texts can 
impact young Black Canadian students. Some may come to reject their race and heritage and internalize a personally-mediated racism that induces a selfperception of white superiority and Black inferiority. It takes a culturally and racially responsive teacher with the capacity to think critically to guide these students in unpacking the images in texts and in interpreting their responses. Studies have shown that in the case of students who are not well grounded in their culture, personally-mediated racism can cause disaffection, resistance to authority, academic underachievement, higher school dropout rates and/or internalized oppression (Dei, 2008; Henry, 1993). Eurocentric narratives work to disempower Black students from a very young age, such that they are unable to resist the epistemic oppression perpetuated by the education system (James, 1995; 1997). Black history courses are critical to preparing educators to promote holistic learning among $\mathrm{K}$ to 12 students, who will thereby come to take pride in who they are and in their culture. For this to happen, universities must equip Black and all teacher candidates with the requisite knowledge and tools to contest the racist representations of Black people that pass for knowledge (Asante, 1987; 2003).

\section{Conclusion}

In Canada, what passes for knowledge is determined by the dominant order; it is hardly surprising that in contrast to peoples of European descent, Black people appear in school syllabi as second-rate citizens. If one of the chief tenets of education is equity, then Canada's mainstream universities are derelict in this respect. Canadian universities must seriously consider including Black history courses in their curricula, and particularly in teacher education programs. Given their anti-racist and non-hegemonic worldview, these courses would serve to educate white and other racialized teacher candidates to value diversity and recognize the importance of interrogating racial privilege, power structures and white supremacy. A teacher education course on Education, Black history and knowledges would offer opportunities to examine curriculum in all subject areas from an Afrocentric lens. For Black teacher candidates and K to 12 students, access to Black and Afrocentric knowledge would afford the opportunity to understand, to far greater effect, what it means to have a Black African heritage (Asante, 2003a). Such knowledge could enable students to relate to their history.

Offering courses on Black history and knowledges could become a reality were universities to decolonize and expand their curricula, commit themselves to eliminating racism vis-à-vis paying lip service to the idea, and hire more Black professors and provide them the resources and support required to design courses that focus on Black history. This approach requires that Black professors be accorded the academic freedom to cultivate in teacher candidates the curiosity and skills to re-examine the curriculum, knowledge and education in general (Vaughn, 
2020). Universities would be required to encourage Black professors to share their knowledge and challenge the injustices Black people experience, including police brutality, academic streaming, real-estate redlining, etc., as well as their implications for the general wellbeing of Black people. Sharing this knowledge with students, from an Afrocentric perspective, would "usher learners into uncharted mental spaces [where they might be empowered to challenge] commonly held beliefs" (Vaughn, 2020, p. 1091).

Furthermore, Black professors ought to be encouraged to challenge teacher candidates' entrenched beliefs and modalities of thought by exposing them to a "Blue epistemology," i.e., stories that are exclusive to the Black experience. The aim here would be to promote "global social justice" (Vaughn, 2020, p. 1091). This would also provide Black students with a platform and voice to resist, redefine and recast colonial and neo-colonial epistemes that "negate Black humanity" (Vaughn, 2020, p. 1094). For example, rather than allow racist narratives to be reproduced, universities should make it easier to access alternative knowledges and literature that examine historical and contemporary social structures that contribute to higher rates of poverty, incarceration, crime, and poor health within Black communities. A "Blue epistemology" is, we believe, one pedagogical approach to helping teacher education candidates transcend racial, class, and cultural barriers to investigating the Black experience as a way for the majority of teacher candidates, especially white teacher candidates, to overcome the obstacles to embracing alternative knowledge systems. Universities might also support Black professors in "plac[ing] African ideals at the center of any analysis that involves African culture and behavior" (Asante as cited in Verharen, 2000, p. 224). These approaches fall under the rubric of a "Blues Methodology," which is a Black Studies theor[y] . . that gives attention to cultural knowledge ... and ... ways of knowing [the] relationships between epistemology, place, and citizenship that transcend boundaries [that] defy form and operate as paradoxical constructions" (Vaughn, 2020, p. 1092). It is also imperative that universities abandon the illusion that they function in a "postracial" environment. White university administrators must recognize that their power to determine the makeup of curricula implicates them in marginalizing Black people and their knowledges. And administrators must recognize that remedies have to be applied at the institutional level.

Lastly, a possible first step in addressing racial inequities within the education system would be to introduce Black-oriented courses as part of a project aimed at exposing teacher candidates to full-spectrum knowledge. Thus, more teacher candidates would come to understand education in a more holistic way and, ipso facto, join others in reforming education at the grassroots level. Adopting this approach would mark the beginning of a fundamental transformation in the Canadian education system whereby schools would become 
nodes of true inclusion, devoid of tokenism and aimed at ameliorating problems rather than solving them. We call on universities to rethink teacher education programs with a view to achieving greater equity, something, we believe, holds the key to building knowledge and fostering a more holistic learning environment.

\section{Notes On The Contributors}

Dr. Patrick Radebe teaches at Lakehead University. His research interests revolve around Afrocentric schools, Black students' education and AfricanCanadian studies. As an educator, watching his students succeed and their confidence grow is one of his many rewards.

Dr. Bathseba Opini is an Assistant Professor in the Department of Educational Studies, Faculty of Education, University of British Columbia. Her research interests include antiracist and decolonizing education, critical disability studies, educational policy and teaching practices.

\section{References}

Allen, A. M. A. (1996). "I don't want to read this": Students' responses to illustrations of Black characters in children's picture books. In K. S. Braithwaite \& C. E. James (Eds.), Educating African Canadians (pp. 147166). James Lorimer \& Company Limited.

Asante, M. K. (1987). The Afrocentric idea. Temple University Press.

Asante, M. K. (1993). Malcolm X as a cultural hero and other Afrocentric essays. Africa World Press.

Asante, M. K. (2003a). Afrocentricity: The theory of social change ( $2^{\text {nd }}$ ed.). African American Images.

Asante, M. K. (2003b). Afrocentricity: The theory of social change. African American Images.

Asante, M. (2007). An Afrocentric manifesto. Polity Press.

Benjamin, A. (2011). Afterword: Doing anti-oppressive social work: The importance of resistance, history and strategy. In D. Baines, (Ed.), Doing anti-oppressive practice: Social justice social work, (pp. 290-297). Fernwood Press.

Boykin, A. W. (1994). Afrocultural expression and its implications for schooling. In E. R. Hollins, J. E. King, \& W. C. Hayman (Eds.), Teaching diverse populations: Formulating a knowledge base (pp. 243-256). State University of New York Press. 
Boynton, S. (2021, February 1). B.C. government urged to officially add Black history to education curriculum. Global News. https://www.msn.com/enca/news/canada/bc-government-urged-to-officially-add-black-history-toeducation-curriculum/ar-BB1diAJT

Canada's Historic Places (n.d.). Oro African Methodist Episcopal Church National Historic Site of Canada. https://www.historicplaces.ca/en/repreg/place-lieu.aspx ?id=12100

Codjoe, H. (2006). The role of an affirmed Black cultural identity and heritage in the academic achievement of African-Canadian students. Intercultural Education, 17(1), 33-54. https://doi.org/10.1080/14675980500502271

Chawane, M. (2016). The development of Afrocentricity: A historical survey. Yesterday and Today, (16), 78-99. http://dx.doi.org/10.17159/2223-0386/2016/n16a5

Crouch, S. (1995). The Afrocentric Hustle. The Journal of Blacks in Higher Education, 10, 77-82. https://doi.org/10.2307/2962771

Daniel, B. J. (2019). Teaching while Black: racial dynamics, evaluations, and the role of white females in the Canadian academy in carrying the racism torch. Race, Ethnicity and Education, 22(1), 21-37. https://doi.org/10.1080/13613324.2018.1468745

Dei, G. J. S. (1996). The role of Afrocentricity in inclusive curriculum in Canadian schools. Canadian Journal of Education, 21(2), 170-186. https://doi.org/10.2307/1495088

Dei, G. J. S. (2008). Schooling as community: Race, schooling and the education of African youth. Journal of Black Studies, 38(3), 346-366. https://www.jstor.org/stable/40034384

Dei, G. J. S. (2013). Africentric schooling: What next? International Journal for Talent Development and Creativity, 1(2), 119-126. https://files.eric.ed.gov/fulltext/EJ1301367.pdf

Dlamini, N. (2002). From the other side of the desk: Notes on teaching about race when racialized. Race Ethnicity and Education, 5(1). 51-66. https://doi.org/10.1080/13613320120117199

Flynn, J., Worden, L., \& Rolón-Dow, R. (2018). The responsibilities of white teacher candidates and teacher educators in developing racial literacy. Multicultural Perspectives, 20 (4), 240-246. https://doi.org/10.1080/15210960.2018.1527156

Gates, H. L. (1991, September 23). Beware of the new pharaohs. Newsweek, 47.

Giroux, H.A., \& McLaren, P. L. (1989). Critical pedagogy, the state, and cultural struggle. State University of New York Press. 
Henry, A. (2015). 'We especially welcome applications from members of visible minority groups': Reflections on race, gender and life at three universities. Race, Ethnicity and Education, 18(5), 589-610. https://doi.org/10.1080/13613324.2015.1023787

Henry, A. (1993) Missing: Black self-representations in Canadian educational research. Canadian Journal of Education, 18 (3), 206- 222. https://doi.org/10.2307/1495383

Henry, F., \& Tator, C. (2012). Interviews with racialized faculty members in Canadian universities. Canadian Ethnic Studies, 44 (2), 75-99. http://doi.org/10.1353/ces.2012.0003

James, C. E. (1995). Seeing ourselves: Exploring race, ethnicity and culture. Thompson Educational Publishing.

James, C. E. (1997). Contradictory tensions in the experiences of African Canadians in a faculty of education with an access program. Canadian Journal of Education, 22, 158-174. https://doi.org/10.2307/1585905

James, C. E., \& Brathwaite, K. (1996). The education of African Canadians: Issues, contexts, expectations. In K. S. Braithwaite \& C. E. James, (Eds.), Educating African Canadians, (pp. 13-31). James Lorimer \& Company Limited.

Kilian, C. (2008). Go do some great thing. The Black pioneers of British Columbia. Commodore Books.

King, L.J., \& Simmons, C. (2018). Narratives of Black history in textbooks: Canada and the United States. In S.A. Metzger \& L.M. Harris (Eds.), The Wiley international handbook of history teaching and learning (pp. 93116). John Wiley \& Sons, Inc.

Lateef, H. (2015). Afrocentricity theory revisited: An alternative framework for assisting Black youth. Perspectives on Social Work, 26- 31. https://hdl.handle.net/10657/5244

Lefkowitz, M. R. (1996). Not out of Africa: How Afrocentrism became an excuse to teach myth as history. Basic Books.

Levine-Rasky, C. (2014). White fear: Analyzing public objection to Toronto's Africentric school. Race, Ethnicity \& Education, 17(2), 202-218. https://doi.org/10.1080/13613324.2012.725043

Macheso, W. P. (2017). The problem with the traveller's gaze: Images of the dark continent in Paul Theroux's The Lower River. Journal of Humanities, 25(2), 45-61.

Manzo, K. (2006). "An extension of colonialism? Development education, images and the media." Development Education Journal 12(2), 9-12.

https://think-global.org.uk/wpcontent/uploads/dea/documents/dej_12_2_manzo.pdf 
Mohamed, T., \& Beagan, B.L. (2019). 'Strange faces' in the academy: experiences of racialized and Indigenous faculty in Canadian universities. Race, Ethnicity and Education, 22 (3), 338-354. https://doi.org/10.1080/13613324.2018.1511532

Morikawa, S. (2001). The significance of Afrocentricity for non-Africans: Examination of the relationship between African Americans and the Japanese. Journal of Black Studies, 31(4), 423-436. https://www.jstor.org/stable/2668024

Murrell, P. (1993). Afrocentric immersion: Academic and personal development of African American males in public schools. In T. Perry \& J. W. Fraser (Eds.), Freedom's plow: Teaching in the multicultural classroom (pp. 231259). Routledge.

Pinar, W. F. (1993). Notes on understanding curriculum as racial text. In C. McCarthy \& W. Crichlow, (Eds.), Race, identity, and representation in education, (pp. 60-70). Routledge.

Simon Fraser University Faculty of Education (2020). Bachelor of education as a second degree.

https://www.sfu.ca/content/dam/sfu/education/educationresponsive/underg raduate/Forms/PDP\%20BEd\%20Second\%20Degree_Summer\%202021.pd $\underline{\mathrm{f}}$

Simon Fraser University Faculty of Education (2020). Undergraduate studies in education.

https://www.sfu.ca/education/undergrad/programs/degrees/bachelor-ofeducation-2nd-degree/overview.html

University of British Columbia (2020). Course schedules. https://teach.educ.ubc.ca/students/courses/

Vaughn, M.S. (2020). Black epistemologies and blues methodologies: Engaging liminal ontological space in qualitative research. Qualitative Inquiry, 26(89), 1090-1101. https://doi.org/10.1177/1077800419883307

Verharen, C.C. (2000). Molefi Asante and an Afrocentric curriculum. Western Journal of Black Studies, 24(4), 223-238.

Woodson, C. G. (1933). The miseducation of the Negro. Associated Press.

Wright, H. K. (2000). Why write back to the new missionaries?: Addressing the exclusion of (Black) others from the discourses of empowerment. In G. J. S. Dei \& A. Calliste (Eds.), Power, knowledge and anti-racism education: A critical reader (pp. 122-138). Fernwood Publishing.

Wright, H. K. (2012). Is this an African I see before me?: Black/African identity and the politics of (Western, academic) knowledge. In H. K. Wright \& A. A. Abdi (Eds.), The Dialectics of African education and Western discourses: Counter-hegemonic perspectives, (pp. 180-191). 